\title{
Assessing Centralized Governance in a Software Cluster
}

\author{
João Paulo L. de Oliveira', José Henrique de S. Damiani², Bruno Brandão Fischer ${ }^{3}$
}

\begin{abstract}
Increasing attention has been paid to the creation of spatially concentrated environments (industrial agglomerations or clusters) that aim at fostering firm-level competitiveness. However, while much has been said about clusters in general, less attention has been paid to structural governance within these agglomerations. This paper discusses the economic dynamics of clusters in the presence of centralized formal body of governance regarding internal and external relationships. We have carried out a case study of the key players in the software industry of Ribeirão Preto, which relies on an institutional arrangement called PISO. PISO arises as an economic institution in the context of Ribeirão Preto's software cluster that structures collective action within the system, interfering in the regional policymaking processes and fostering an environment that improves overall capabilities that allow firms to take full advantage of the externalities in order to create and consolidate competitive local advantages.
\end{abstract}

Keywords: clusters; governance; innovation; industrial agglomerations; collective efficiency.

\footnotetext{
1,2Instituto Tecnológico de Aeronáutica, Department of Production Engineering, 50, Praça Marechal Eduardo Gomes, I2228-970, São José dos Campos, SP, Brazil. e-mail: 'joaoleo@gmail.com; ²damiani@ita.br

${ }^{3}$ Grupo de Investigación en Economía y Política de la Innovación, Universidad Complutense de Madrid, Finca Mas Ferré, Edificio A, Campus de Somosaguas, 28223, Pozuelo de Alarcón, Madrid, Spain. e-mail: bbfischer@pdi.ucm.es
}

ISSN: 07I 8-2724. (http://www.jotmi.org)

Journal of Technology Management \& Innovation (c) Universidad Alberto Hurtado, Facultad de Economía y Negocios. 


\section{Introduction}

The success of industrial districts became a topic of strong interest among economics' scholars in the 1980's. Since then, increasing attention has been paid to the creation of spatially concentrated environments that aim at fostering firm-level competitiveness through promotion of backward and forward linkages, as well as other forms of positive externalities that are expected to lead to higher levels of productivity and innovativeness (Storper and Allen, 1995; Cooke et al, 1997; Asheim; Gertler, 2006; Shearmur, 20I I). Consequently, especially since the 1990's, policymakers also became interested in concepts related to agglomeration economies, particularly those related to industrial clusters. This scenario is a result of the strong relationship between overall competitiveness and geographic proximity, where a self-reinforcing system is expected to take place (Cassiolato and Lastres, 2002; Porter, 1998; Barquero, 2005).

Thus, we can highlight a relatively stable consensus among researchers and policymakers on the importance of prioritizing the development of supportive environments for firms - particularly SMEs - which are in productive agglomerations. This orientation differs from the perspective based on large companies' support. One reason for this shift in focus is a commitment to the development of SMEs as mechanisms for strengthening social stability of the countries, by stimulating endogenous growth in underprivileged areas. With this goal in mind, industrial policies tend to be directed towards identifying methods and initiatives that can create and/or strengthen productive relationships at the local level (Bianchi, 1996) by adopting a systemic view of economic phenomena. Hence, clusters represent an increasingly prominent item on the development agendas of local economies throughout the world, since they address issues of competitiveness and innovation through a systemic approach (Tristão et al, 20I3), i.e., binding together sets of agents with complementary capabilities (Saraceni and Andrade Júnior, 2012).

In this approach it is argued that the involvement of firms and industries in the market dynamics is likely to promote the necessary conditions for an effective innovation-based competitive environment (Bianchi, 1996), following the basic structure of Schumpeter's Mark I.What we notice is that the traditional approach emphasized protectionist policies and encouraged a deliberate process of economic concentration, reducing internal competition in favor of an expected national benefit. Such way of thinking economic growth finds limited empirical support (an illustrative case would be that of South Korea), but it is usually dependent upon highly centralized institutional systems (which are hardly compatible with democratic institutions). Hence, the current focus lies widely on promoting innovation-based stimuli perpetrated at the local-regional levels, where agglomerative structures play a central role in related policymaking processes.

Nonetheless, specific methodologies on how to implement, develop and manage these clusters still face several challenges, since economic planning is contingent upon multidimensional constraints. One concept that lies at the core of clusters' efficiency is that of technological and knowledge spillovers. Clusters' internal relationships must be considered in defining how the different parts interact with each other and with external agents. It is necessary to analyze how local economies are positioned in the global economy, which are the interests of external stakeholders and how these interests affect the governance structure of these regions (whether favorably or not). Ultimately, we are interest in identifying how these factors reflect on the macroeconomic development. Such considerations modify the possibility of promoting local development from the "industrial district model". Policies which focus only on local relations can threaten the development process of the country, since national policies and practices regarding geographic distribution of power between the international and sub-national agencies have a central role in the process of articulation, for what should be the basis of the observed links between internal and external agents.

On the other hand, while much has been said (and empirically tested) about clusters in general, less attention has been paid to structural governance within these agglomerations. Having in mind that clusters not only improve insiders' competitiveness, but also that they generate systemic spillovers, the policymaking process of cluster intervention remains a blurry field in academic research. It is from this perspective that this paper discusses the economic dynamics of clusters in the presence of centralized formal body of governance regarding internal relationships between agents, as well as their aggregate relationship with external parties. In order to comply with our goal we have carried out a field survey in the form of interviews with key players in the software industry of Ribeirão Preto, which relies on an institutional arrangement called PISO. PISO functions as a catalyst of cluster interactions, directing efforts and strengthening overall capabilities.

Our departure point makes reference to the perspective that power relations within clusters, including their governance structures, are matters that influence the interorganizational dynamics and aggregate performance of firms (Sugden et al, 2005; Lin et al, 20I2; Bathelt and Taylor, 2002). This is only logical when it is taken into account that cluster-based initiatives rely on the connectivity between agents. Reducing frictions and maximizing benefits from these interactions become key in defining the long term behavior of any given cluster. Nonetheless, the role of centralized organizational 
structures in industrial agglomerations has received scarce attention in previous research (Reinau and Dalum, 2008).

The article is structured as follows: firstly, we discuss the main theoretical foundations of industrial agglomerations and aspects related to their economic dynamics (sections 2 and 3 ) and propose an operational definition of the core concepts regarding industrial clusters (section 4). After that, the methodological rationale behind our case study is outlined. In section 6 we briefly discuss the economic structure of Ribeirão Preto, focusing on the characteristics of its software industry. Section 7 presents the results of our empirical analysis, and section 8 concludes with final remarks and implications of our assessment.

\section{Foundations of agglomeration economies: the mar- shallian perspective}

Literature suggests several approaches to productive agglomerations (Marshall, 1920; Krugman, 199I; 1998a; 1998b; Casarotto and Pires, 200 I; Cassiolato and Lastres, 2003; Suzigan et al, 2003; 2005; Porter, 1990; 1998). The Marshallian theory is the starting point for all studies related to clusters of firms. Marshall (1920) observed industrial districts in Britain in the late nineteenth century, and found that the presence of firms concentrated in one region can provide all producers with competitive advantages that would not exist if they were working in isolation. The main factors which justify the importance of geographical location are threefold:

i. Labor market pooling;

ii. Vertical entrepreneurial relationships (input-output sharing); and

iii. Knowledge and technological spillovers.

Marshall referred to these factors as "external economies" (Marshall, 1920; Meyer-Stamer and Harmes-Liedtke, 2005), which represent somewhat intangible resources that have systemic impacts on agglomeration of firms. Ultimately, this approach represented a core feature of economic growth theories in the twentieth century as it formally introduced the concept of increasing returns to scale in the realm of mainstream economics.

Hence, Marshall (1920) is considered the pioneer in the concept of agglomeration economies on economic theory. Analyzing industrial organization, he realized that the increasing emphasis on division of tasks, resulting from the advantages of the principle of division of labor, entailed a differentiation in the industry. Such differentiation was characterized by the development of labor specialization, knowledge pool and availability of productive resources (Marshall, 1985). Moreover, he identified an integration process where stronger relationships and connections between different parts of an industrial organism generate increased stability in the economic structure as a whole.

Consequently, the concentration location of industries allowed the gradual implementation of improvements and advancements of division of labor, both in operational processes and practices of business administration (Marshall, 1985). The main reasons that influence the location of concentrated industry are in physical conditions: availability and quality of natural resources, proximity to sources of raw materials and production inputs and easy accessibility through alternative transportation. Marshall emphasized the importance of the presence of a demand in the locality endowed with high purchasing power and a sophisticated consumer standard, demanding a high level of quality, and the consequent attraction of skilled workers. The rich contingent gathered in a particular location would give rise to a demand for goods of an exceptionally high quality, attracting skilled workers from other regions, while also educating local workers (Marshall, 1985).

Furthermore, Marshall addressed economic dynamics under a different scope from that of classical economics. In his viewpoint, equilibrium was not necessarily a natural outcome of interactions: a demand for an industrial organization, motivated by a simple desire, would not necessarily generate an offer. Thus, demand should translate a concrete and real need to be efficient in the sense of being willing to pay an adequate remuneration to agents who have conditions and motivation to meet this need. These economic agents, depending on the size and efficiency of demand, will be organized in manufacturing units of different sizes and tend to be located geographically near the sources of inputs and consumer markets alike (as in a "gravitational" structure, following Krugman's (199I) model of economic geography). In developing its industrial and commercial activities, firms would steer their business in a constant search for cost reduction and continuous profit maximization. Marshall believed that many of the economies related to the use of skilled labor and specialized machinery, commonly considered peculiar to very large establishments, did not depend on the size of individual factories. While some depend on the total volume of production of the same genus of neighboring plants, others depend mainly on the total volume of production in broader geographical regions (Marshall, 1985). Consequently, this perspective marks the foundations of the economics of increasing returns to scale, a theoretical landmark for understanding the spatial division and concentration of productive activities (and even the rationale behind the formation of large urban areas).

Marshall then introduces two technical terms in his analysis. He divides the savings derived from increased scales of production into two categories: those that depend on the 
overall development of the industry, which he calls "external economies", and those that depend on the internal capabilities of firms (productive efficiency and managerial quality), which he calls "internal economies". At this point, he asserts that the external economies can often be achieved by the concentration of many small businesses alike in spatially concentrated locations (Marshall, 1985).

Externalities can be defined as the effects generated by an economic agent when running a productive activity or consumption that will affect, positively or negatively, the productive activity or consumption of other economic agent, which cannot be offset by the interference of another agent (Kolstad, 2000). This interference can be expressed in terms of external diseconomies, or when social costs exceed private costs. If the agent imposing external diseconomies and the agent who suffers them can negotiate these diseconomies, then state intervention would be unnecessary to ensure an optimal allocation of resources (Turvey, 1963). From this logic, it becomes clear that externalities represent a case of market failure. This assertion is key to understand the need for institutional intervention regarding externalities (be they positive or negative) in order to provide economic systems with optimized results.

In the case of industrial agglomerations, focus lies usually on the positive side of externalities. Advances in the state of arts of operational and administrative processes, machinery and equipment and products in a given location are likely to spread rapidly to the whole industry. This process is referred as knowledge (or technology) spillovers, which can flow more easily in geographically concentrated structures, establishing a "neighborhood advantage" regarding businesses and professionals, thus creating an atmosphere and a climate for increased economic activities and the introduction and development of new businesses.

The theoretical basis for the economic evaluation of externalities lies on the field of welfare economics, which identifies that social costs of products or services should compute all costs involved in its production, thus including external costs that production or byproducts can generate. If these costs are not taken into account, social costs of producing a given good will be different from private costs, thus poten- tially leading to significant distortions in resource allocation. On the other hand, as disadvantages of geographical concentration of industry, Marshall (1985) points out the aspects related to the existence of few occupations in the region, a significant specialized and high cost of hand labor for businesses and the fact the region has only one dominating industry. This could lead to a condition of extreme vulnerability to stability and productive evolution in the region, provided that economic systems in capitalist economies are bound to constantly face creative destruction. Also, the risks of an interruption in the supply of raw materials and inputs required for the functioning and continuity of operations could represent significant pitfalls for regional growth over the long run.

A general discussion of Marshall (1985) resides in the fact that an increase in the overall amount of production of a given product would generate increasing returns to scale, hence having impacts on the size of firms. This can be translated into higher levels of aggregated productivity (TFP or Total Factor Productivity). The law of increasing revenue can be expressed as follows: An increase of labor and capital leads generally to a better organization, which increases the productivity of the action of labor and capital (Marshall, 1985). This proposition creates the theoretical basis for cluster promotion, as these are likely to benefit the socioeconomic system as a whole.

\section{An eclectic approach to the economics of agglom- erations}

In this section we briefly review the most relevant economic developments that follow the seminal propositions of Marshall regarding the phenomenon of industrial agglomeration. Our intention is to discuss the main topics and contributions of a few schools of thought that can substantially contribute to our analytical effort. Namely, we address the New Economic Geography approach, the developments of Michael Porter regarding clusters inside the Business Economics' rationale, the Innovation Economy perspective, and Schmitz's Collective Efficiency. Our assessment does aim at scrutinizing each of these approaches thoroughly, but rather to provide an eclectic overview of theory in order to achieve sound support for our empirical exercise.

\begin{tabular}{|c|c|}
\hline Centripetal Forces & Centrifugal Forces \\
\hline Market size effects (linkages) & Immobile factors \\
\hline Thick labor markets & Land rents \\
\hline Pure external economies & Pure external diseconomies \\
\hline
\end{tabular}

Figure I. Forces affecting geographical concentration Source: Krugman, 1998b.

ISSN: 07I 8-2724. (http://www.jotmi.org)

Journal of Technology Management \& Innovation (c) Universidad Alberto Hurtado, Facultad de Economía y Negocios. 
The New Economic Geography (NEG) approach originated from the classical theory that seeks to explain the spatial nature of economic activities. It highlights the importance of Marshallian externalities, such as specialized labor markets, historical factors and geographical location and service industries. Economies of scale leverage the geographic concentration of certain activities, and the local external economies have incidental character and operate attractive forces (centripetal forces) and repulsive (centrifugal forces) ventures to certain agglomeration of firms (Krugman 1991; 1998a; 1998b). Thus, the dynamics of the agglomeration processes heavily depends on the balance between these forces. An outline of these features is summarized in figure $\mathrm{I}$.

One of the great accomplishments of NEG theory is related to its capacity of generating knowledge regarding macroeconomic and regional planning. By approaching economic functions through spatially-oriented models, NEG has been capable of offering insights that Marshall's approach could only remotely suggest. This is the result of applicable mathematical models that can be extensively replicated throughout the world in various kinds of economic systems. Therefore, the impacts of NEG upon the analysis of clusters is can be described as fundamental for understanding agglomerations' formation and behavior over time.

Another important field of agglomeration studies is that of Business Economics, closely related to the developments of Michael Porter, from Harvard University. This approach seeks to explain the sources of wealth of modern nations in the global economy through analytical exercises of aggregate firm-level behavior. In this regard, the world's economic map is understood as a division of industrial clusters of excellence, which represent critical masses of productive agglomerations of companies located in regions with competitive success in particular areas. The competition among companies, and vertical cooperation, represent the main ways to increase the competitiveness of nations (Porter, 1990; 1998; 1999; 200I). Following Porter's approach to clusters, governmental interventions on local-level infrastructure would enhance regional capacity to develop sustainable agglomerations. Nonetheless, Porter (1998) gives great emphasis to the fact that "natural" clusters should be supported (in opposition to top-down clustering initiatives).

The Innovation Economy approach (Cassiolato and Lastres, 2003; Breschi and Malerba, 1997) focuses on technological development and the formation of innovation systems arising from the interaction of businesses and other organizations. To Cassiolato and Lastres (2003), innovation and knowledge configure central elements of the dynamics and growth of organizations, regions and nations. The innovation and learning are strongly influenced by economical, social and political contexts, and are viewed by these authors as processes dependent interactions. These interactions occur mainly through the establishment of common codes of communication and coordination. Within the vast field of innovation studies, this approach can be located inside the concept of Regional Innovation Systems, which pays attention to microeconomic interrelations in geographically bounded territories (Morgan, 1997). Interestingly, the RIS approach provides similar insights to those of the Business Economics' literature, where public intervention is understood as a catalyst of agglomeration process, instead as an active promoter of economic activity (Morgan, 1997).

Furthermore, the RIS approach is largely oriented towards the generation and diffusion of knowledge within local systems, which can only be achieved through an adequate institutional environment (Malecki, 2004; Cooke et al, 1997; Asheim and Gertler, 2006; Shearmur, 201 I). Florida (1995) adds to this context the importance of well developed governance systems for the efficient coordination of inter-firm interactions, setting the stage for a theoretical integration between Transaction Cost Economics and macroeconomic phenomena such as industrial agglomerations.

The approach of Collective Efficiency has Schmitz (1997; 1999) as the main author. According to this view, it is the combination of two factors that produces competitive advantage: i) the spontaneous local external economies; and ii) joint deliberate actions from firms in the same sector. Schmitz referred to such combination of factors as Collective Efficiency. Again, we can notice that economic performance is shaped by an arrangement of pure-market behavior and structured coordination regarding agents' strategic interests. These joint actions can occur in two ways:

i. Horizontally: sharing and exchanging of equipment and information between companies in the same sector;

ii. Vertically: generation of alliances and associations between end users and suppliers.

This particular perception on the dynamics of clusters is of interesting utility for validating core role played by interfirm interactions in the process of generating competitive agglomerations of firms. Even though this issue is extensively dealt with by the previous schools of thought, the Collective Efficiency approach tackles this specificity of clusters more directly, thus concentrating its analysis to the dynamics of connections between agents and how they can have significant impacts upon overall performance.

In order to summarize the core contributions of the theoretical background described above, table I offers the main insights and central references for the construction of our analytical framework. 


\section{Conceptual landmarks for analysis of clusters}

Literature presents a varied typology of productive agglomerations of companies, since they have different applications according to the concept of multiple contexts. Lorenzen (2005) refers to the heterogeneity in terms of conceptual definitions as a "terminological soup". Nonetheless, some key elements must be taken into account in the process of agglomerations' analysis and frameworks:

i. Geographic Concentration: organizations are located in different geographical regions due to factors such as external economies, social capital, availability and quality of resources, communication facilities and transport costs. Furthermore, the role of historical accidents and chance is of paramount importance in defining where such concentration will take place;

ii. Specialization: the agglomeration functions as a living core of the main industrial activities in a given sector (or set of sectors), to which all other agents are connected; iii. Multiple agents: the agglomeration goes beyond the proximity between units of enterprises, since they also comprehend public authorities, educational systems, financial sector, among other institutional bodies;

iv. Competition and Cooperation: it characterizes the existing duality regarding interrelations between agents involved in the agglomeration;

v. Critical mass: required to ensure the dynamism of agglomeration and external economies;

vi. Life Cycle: agglomerations are not temporary, short-term, economic structures. They inherently connected with evolutionary behavior.This does not mean, however, that such evolution will not lead to eventual decay, as creative destruction processes largely affect the economic status quo in the long run;

vii. Innovation: the cluster of organizations is involved in continuous processes of technological, commercial and organizational change. The intensity with which it occurs depends on the sector of activity and on the capabilities of companies that integrate the agglomeration;

\begin{tabular}{|c|c|}
\hline Approach & Emphasis \\
\hline $\begin{array}{l}\text { Marshall: Marshallian External } \\
\text { Economies }\end{array}$ & $\begin{array}{l}\text {-Proximity and interaction; } \\
\text {-Increasing returns to scale; } \\
\text {-Advances in the division of labor; } \\
\text {-Availability and quality of resources; } \\
\text {-Easy accessibility; } \\
\text {-Demand with purchasing power; } \\
\text {-Attraction of skilled workers; } \\
\text {-Quick dissemination for the entire industry; } \\
\text {-Regional economic risk and high vulnerability due to lack of industrial diver- } \\
\text { sification; }\end{array}$ \\
\hline $\begin{array}{l}\text { Krugman: New Economic } \\
\text { Geography }\end{array}$ & $\begin{array}{l}\text {-Emphasizes the importance of Marshallian externalities; } \\
\text {-Centripetal forces; } \\
\text { Centrifugal forces. }\end{array}$ \\
\hline $\begin{array}{l}\text { Porter: Business Economics' } \\
\text { Approach }\end{array}$ & $\begin{array}{l}\text {-Explains the sources of wealth of modern nations in the global economy } \\
\text { dominated by economic clusters located in regions with competitive success in } \\
\text { particular areas; } \\
\text {-Competition and cooperation are the main ways to increase the competitive- } \\
\text { ness of a nation. }\end{array}$ \\
\hline $\begin{array}{l}\text { Lastres and Cassiolato: Inno- } \\
\text { vation Economy }\end{array}$ & $\begin{array}{l}\text {-Technological development; } \\
\text {-Formation of innovation systems arising from the interaction between differ- } \\
\text { ent organizations existing in the cluster; } \\
\text {-Innovation and knowledge contexts influenced by economic, social and insti- } \\
\text { tutional contexts. }\end{array}$ \\
\hline Schmitz: Collective Efficiency & $\begin{array}{l}\text {-Combination of external economies and joint actions deliberate sector compa- } \\
\text { nies produces competitive advantage called collective efficiency; } \\
\text {-Horizontally: sharing resources and information; } \\
\text {-Vertically: creating alliances. }\end{array}$ \\
\hline
\end{tabular}

Table I.An eclectic overview of industrial agglomerations

ISSN: 07I 8-2724. (http://www.jotmi.org)

Journal of Technology Management \& Innovation (c) Universidad Alberto Hurtado, Facultad de Economía y Negocios. 
viii. Culture and Institutional Environment: these elements are of great value for the effective development of the dynamics of agglomeration. While both are broadly recognized in literature, they receive little attention in policymaking processes regarding cluster-related interventions.

Agglomerations can also be defined and conceptualized according to their level of development. This is an issue of utmost importance, since clusters are usually highly heterogeneous in terms of their overall competitiveness, as well as their capacity of generating spillovers and generating self-organization capabilities. When cluster analysis is carried out, taking into account such aspects becomes of paramount importance. Table 2, below, summarizes some key dimensions in this regard:

To these general aspects, we ought to add that, at any given level of development, a central factor for the cluster performance is the way in which its governance system is structured. If we consider that there is widespread agreement that clusters' advantages are tightly related to connections between agents, institutions and other stakeholders, the way in which such relationships occur is a logical driver of overall performance.

The determinants of the governance structure in clusters lie at the core of several analytical approaches. Much of these approaches specifically address governance in production systems organized in networks or supply chains led by leading companies, which are often outside the local system (Gereffi, 1994; Markusen, 1996; Sturgeon, 1997, among others). In contrast to these approaches, Lombardi (2003) analyzes the strategic control exercised by agents on local production systems by controlling the flow of information and knowledge about demand characteristics, type of product and market trends. Scott (1998) demonstrates the importance of the social construction of political and cultural assets located as a basis for collective action.

Based on the original contributions of Williamson (1985), Storper and Harrison (199I) assess the issue of governance by analyzing the hierarchies that are formed within the chain of production and distribution of goods. They use the concept of production system, which defines the coordination structure of interactions that occur along the supply chain. These relationships can be of a vertical or horizontal nature, and they can be governed by different organizational forms ranging from pure-market market mechanisms to hierarchy. From this concept, the authors try to analyze the governance structure present in these relations, i.e., the degree of hierarchy, leadership and command (or, alternatively, collaboration and cooperation) among the companies participating in productive systems.

The governance structure is shaped by power relations (or cooperation) along the chain of production and distribution of goods. Therefore, Storper and Harrison (I99I) seek to establish whether, and to what extent, relationships within production systems affect the degree of control in governance structures, or if formal coordination structures can be replaced by trust generated from frequent interactions between agents. The high frequency of interactions arises from the division of labor between specialized producers and suppliers, resulting in competitive gains for firms participating in the production system and various externalities. The authors hypothesize that this cognitive proximity would result in higher degrees of collaboration and cooperation between companies by reducing risks of opportunistic behavior.

As it can be gathered from the framework designed above, clusters are often understood as self-organizing entitities when it comes to governance structures. Though firms' relationships with the institutional environment are recognized, little attention has been paid in literature regarding the moderating role that formal and centralized governance structures can influence systemic results. As outlined in the introductory section, this issue lies at the core of our empirical examination. Tripsas et al (1995) in a context of interfirm collaboration (without assessing clusters specifically) found support for the hypothesis that third-party support for company's interactions significantly reduce relationships' frictions.Accordingly, we develop the methodological rationale of our study in the next section, aiming at verifying such dynamics in a cluster in Brazil.

\begin{tabular}{|l|l|}
\hline Author & Factor \\
\hline Suzigan (2003) & Degree of Economic Importance for the sector and the region \\
\hline Frigero (2006) & Economic, technical and cultural impacts \\
\hline Lastres and Cassiolato (2003) & Degree of organization and knowledge \\
\hline
\end{tabular}

Table 2. Level of Development of Agglomeration

ISSN: 07 I8-2724. (http://www.jotmi.org)

Journal of Technology Management \& Innovation (c) Universidad Alberto Hurtado, Facultad de Economía y Negocios. 


\section{Methodological rationale}

The empirical driver of this research lies on an exploratory case study of PISO, Ribeirão Preto's Software Industry Pole, located in the State of São Paulo, Brazil (www.piso.org. br). PISO was established in 2004 as NGO that comprises software firms in order to generate better sectoral coordination, structuring backward and forward linkages, and developing closer interactions with governmental bodies. In this regard, PISO functions as a coordinating agent of the software industry in Ribeirão Preto, structuring the institutional environment by creating a formal and centralized body of governance for the software agglomeration in this particular region. As previously stated, this approach offers an introductory analysis of such form of cluster organization and policymaking. While self-organizing industrial districts have been extensively studied in the fields of economics and management, little attention has been paid to less spontaneous forms of agglomeration. Further details regarding the local economic environment and characteristics of PISO are presented in sections 6 and 7 below.

In order to develop a comprehensive analysis of PISO, our methodological rationale is largely based on the structure proposed by Sugden et al (2005), where an analytical framework for case studies on cluster dynamics is defined by: i. The cluster and the locality: the geographic and economic context of the cluster;

ii. Linkages and Networks: interfirm interactions within the cluster;

iii. Cluster governance: the structure of decisions and power relations within the cluster;

iv. Learning: learning processes which reinforce the knowledge pool within the cluster ;

This basic framework functions as an important pillar for carrying out the analysis of clusters' dynamics. Nonetheless, we believe that some additional dimensions can be beneficial in order to develop a more rigorous case study. In this sense, we have also included some specific aspects regarding internal rivalry within PISO, as well as some remarks on the connectivity between the cluster and its socioeconomic environment. While the former aspect is of paramount interest in the assessment of cluster governance, the latter can shed light on the cluster's embeddedness with its surrounding systems.

The specific object of study is represented by PISO's companies, as well as the centralized organizational management of the cluster (PISO administration itself). Desk research and case study (Yin, 200I) were conducted to gather information on the dynamics of the centralized formal structure

\begin{tabular}{|c|c|}
\hline Step & Fundamental Aspects \\
\hline $\begin{array}{l}\text { 1. Deepening the understanding of the } \\
\text { externalities generated by thematic } \\
\text { clusters, their constraints and analytical } \\
\text { foundations }\end{array}$ & $\begin{array}{l}\text { - Marshall: Marshallian External Economies } \\
\text { - Krugman: New Economic Geography } \\
\text { - Porter: Addressing the Economics of Business } \\
\text { - Lastres and Cassiolato: Innovation Economy } \\
\text { - Schmitz: Collective Efficiency }\end{array}$ \\
\hline 2. Interview Roadmap & $\begin{array}{l}\text { - Importance of geographical location } \\
\text { - Intensity of interaction and cooperation between companies } \\
\text { - The importance of the rivalry factor upon competitiveness; } \\
\text { - Existence of interactive learning and search for innovation } \\
\text { - Existence of collective efficiency resulting from the deliberate joint } \\
\text { action between different agents } \\
\text { - Governance structure within the cluster }\end{array}$ \\
\hline $\begin{array}{l}\text { 3. Conducting Interviews (July/Septem- } \\
\text { ber 2012) }\end{array}$ & $\begin{array}{l}\text { - President } \\
\text { - Financial Director } \\
\text { - Director of Investor Relations } \\
\text { - Director of Technology } \\
\text { - Operations Manager }\end{array}$ \\
\hline 4. Analytical Procedures & $\begin{array}{l}\text { - Making collective sense of interviews } \\
\text { - Analytical development of data } \\
\text { - Propositions regarding theoretical and practical implications }\end{array}$ \\
\hline
\end{tabular}

Table 3. Methodological steps

ISSN: 07I 8-2724. (http://www.jotmi.org)

Journal of Technology Management \& Innovation (c) Universidad Alberto Hurtado, Facultad de Economía y Negocios. 
of governance regarding Ribeirão Preto's software cluster, following the abovementioned constructs. This approach was developed through in-depth interviews and direct observation with members of the relevant organizations (firms and PISO).

Table 3 summarizes our methodological rationale with focus on operational aspects of our research, highlighting the main aspects that were considered throughout our assessment on the economic and managerial dynamics of PISO.

In sections 6 and 7 we present the empirical outlines of our research. Firstly, a general exposition of Ribeirão Preto's economic context is presented. Since the nature of our research lies on geographical dynamics of economic activity, having a clear picture of the underlying landscape becomes mandatory. Next we present the main findings of the case study.

\section{Economic context and the software industry scenar- io in ribeirão preto}

Ribeirão Preto is a Brazilian city in the State of São Paulo, $310 \mathrm{~km}$ distant from the local capital. In 2012 its population was estimated by IBGE (Brazilian Institute for Geography and Statistics) in 619,746 inhabitants (eighth most populous city in the State of Sao Paulo), with $99.7 \%$ of its population living in urban areas.

Ribeirão Preto was founded in 1856 as a typical agricultural town. However, in the second half of the 20th century it began to receive investments in the areas of health, biotechnology, bioenergy and information technology. Besides being a national reference in the health sector, Ribeirão Preto has been gaining attention in the software industry . In this sense, PISO was established in 2004 through the initiative of nine companies as a nonprofit association. PISO has received nationwide recognition because of its work for the progress of the IT sector and professional software industries, turning Ribeirão Preto into a national hub concerning these activities.

In the region of Ribeirão Preto, according to data from RAIS (20I2), there were in 2010 around 98 software companies, mostly small and micro enterprises. Also, it is noteworthy that many companies in the software have emerged as spinoffs from local universities. The SUPERA (Business Incubator of Technology), held by FIPASE (Foundation Institute for Advanced Health), has contributed to nascent software companies by offering managerial support in their early stages of operation, increasing the chances of success. In early 2012, there were nine software companies incubated, associates or already graduated in SUPERA.
Ribeirão Preto is the city in the State of São Paulo with the largest number of companies with MPS.BR certification (24 companies). This certificate is issued by Softex , in partnership with the Ministry of Science, Technology and Innovation, related to software process improvements. This aspect reflects a an important feature of the software sector in Ribeirão Preto, since investment in signaling mechanisms such as MPS.BR represents higher quality standards in products and services, as well as long-term planning and the pursuit of competitiveness in international markets.

This broad context provides some interesting insights on the dynamics of the cluster under scrutiny. First of all, it should be noticed that the agglomeration of software firms in Ribeirão Preto is not a result of directed efforts, i.e., from a planned initiative to generate a cluster. While this research does not entail the analysis of the cluster's origins, we firmly believe that historical junctures (Krugman, I99I; 1998a; 1998b) play a central role in establishing the critical mass required for geographic concentration of economic activities to take place. Nonetheless, institutional support has been enhanced through upsurge of PISO, thus strengthening companies' capabilities to become nationally and internationally competitive. Since feedback loops are ubiquitous in economic systems, such kind of intervention is likely both to respect the market's allocation of resources, and to reinforce the nature and externalities of the software cluster in Ribeirão Preto, which is in accordance with Porter's (1998) propositions.

\section{Results}

As previously highlighted, the central objective of this study consists in exploring the key managerial characteristics and economic dynamics of PISO (understood as a centralized form of cluster governance) in order to build rigorous foundations for further analytical exercises, as well as to offer insights for policymakers. Thus, based on the theoretical framework presented and on the methodological rationale proposed, this section addresses the results of the case study conducted in the software industry in the region of Ribeirão Preto.

Besides initiatives involving courses, lectures and workshops for business improvement and staff members, PISO also has programs that encourage the training of skilled labor. An outcome of these activities is that the macro region of Ribeirão Preto is amongst the top 20 in Brazil in terms of ICT employment. This aspect is directly related to the creation of a critical mass of skilled labor at the local level.

During $20 \mathrm{II}$, the member companies of PISO achieved revenues of around USD 100 billion (by exchange rates of that year) and an increase of $20 \%$ took place in 2012 , signaling the 
rapid dynamics of growth of this particular cluster. In terms of employment, Ribeirão Preto's software firms absorbed 927 workers in 2010 (RAIS, 20I2). With the growth of the sector in 20II and considering professionals who develop software internally, i.e., within companies in other sectors, it is estimated that the current number of employees in this sector exceeds 2,000 people. These professionals earned an average monthly salary of $R \$ 2,249.78$. Interestingly, PISO's members paid an above average wage ( $R \$ 2,969.54)$. In overall figures, the software industry in Ribeirão Preto ranks amongst the ten sectors in services' industries with higher wage levels.

Due to the need for skilled labor, there are many systems in the area of training, ranging from technical education to undergraduate and graduate studies. Considering only undergraduate education, majors are granted according to both generic specializations (such as Information Systems) and specific fields of study (such as Biomedical Computing). There are currently 8 Higher Education Institutions in Ribeirão Preto that offer programs in theses fields.

Among the main objectives of PISO we can mention the promotion of professionalization in software industries in the Ribeirão Preto region, protecting the interests of member companies in negotiations with governmental bodies, the promotion of projects for social inclusion in economically laggard communities through training of skilled labor to meet the demand of associated companies (digital inclusion). Furthermore, PISO has fostered the following working groups:

i. Technology Forum: aims at presenting and discussing the state of the art in the IT industry. This particular initiative functions as a catalyst of knowledge flows amongst members of the cluster;

ii. Training Programs: it not only generates improvements on the capabilities of employees, but it also helps to bring the labor market to an equilibrium by increasing the critical mass of skilled professionals in the region;

iii. Technology Condo: the goal of this initiative is one of providing an area for software companies to locate their headquarters, thus fostering proximity benefits. This condominium will feature a complete infrastructure (training halls, parking for independent companies, common dining hall, meeting rooms etc.);

iv. Human Resources: it discusses matters of common interest to PISO's member companies in the HR field, studying, researching, and sharing ideas for implementing HR practices, such as standardization of business positions, salary and benefits' surveys in the IT market.

The main objective is to strengthen the PISO segment in order to share ideas, discuss problems common to all, in- creasing the bargaining power of companies and reduce investment costs. More than that, however, we can analyze such behavior from PISO as functioning as a catalyst in the processes that lie at the core of agglomeration economies. In its role of a centralized body of governance, PISO is able to optimize overall performance without interfering in the natural dynamics of agglomeration.As a consequence, PISO's member companies have distinguished themselves in:

i. Encouraging relationships between companies in the software industry, thus developing an above average cooperative behavior;

ii. Preserving ethical standards of conduct in the negotiations on market information technology (IT), generating credible signals of relationship quality, thus reducing transaction costs through trust between agents. These include:

- Avoiding procedures that constitute the creation of artificial market conditions, such as price manipulation, fraudulent operations and use of unfair practice in market operations;

- Honoring transactions agreed between the companies;

- Not committing acts of unfair competition of any kind;

- $\quad$ Preserving the confidentiality of data and information they receive, handle or archive, not using or disclosing to benefit himself or others;

iii. Promoting and encourage the development and human capacity building.

Furthermore, PISO has developed approaches to mobilize software firms in Ribeirão Preto towards the importance of MPS.BR (Process Improvement of Brazilian Software), a form of quality assessment of information technology companies that emerged in Brazil in 2002, based on the Capability Maturity Model Integration (CMMI), global reference model in several market sectors, encouraging PISO's members to engage in internationalization activities.

Such initiatives have been able to strengthen the competitive conditions regarding PISO's members. Some of these tangible outcomes are listed below:

i. Reducing tax rates applicable to software companies in the city of Ribeirão Preto to levels that match those of neighboring cities. By representing a cluster of companies in an unified manner, PISO achieved higher bargain power with local institutions in comparison to what would exist in the absence of a coordinating body;

ii. Agreement with Softex. PISO facilitated an agreement with Softex that initiated the processes related to the implementation of MPS.BR and its related quality standards. 
Resources from the International Development Bank were used in the first stages of the certification procedures. Member companies that did not participate in this initiative were also benefited by attending courses in Campinas Softex as associated companies;

iii. Technological cooperation agreement, with the aim of promoting the exchange of experiences among member companies and creating solutions that benefit the cluster as a whole, through the application of methods traditionally used for the production of software in a productive platform, comprehensive and innovative. It also seeks to assist companies in their technological upgrading;

iv. Promoted more than 27 courses, enabling around 680 professionals;

v. Established a direct communication channel with the largest worldwide entity in Project Management - PMI ${ }^{\circledR}$.

Moreover, in addition to the individual partners, PISO has dedicated efforts regarding the formation of extra-cluster ties. Currently, PISO has the following institutional partnerships that benefit the whole agglomeration of member firms:

i) ACIRP: Commercial and Industrial Association of Ribeirão Preto;

ii) SEBRAE: Entrepreneurship Support Program; iii) SOFTEX: Association for Promotion of Brazilian Software Excellence;

iv) CIESP: Industrial Association of the State of São Paulo.

While over the years of operation PISO has established itself as a significant entity, representative of an industrial agglomeration of high value-added products, on the other hand, some barriers identified by the business cluster deserve attention:

- Tax rates: this sector is a strong generator of employment in relation to revenue. High tax charges ultimately lead companies to seek other forms of employment, contracts for services, cooperatives, and others. A smaller tax load would allow businesses to hire industry professionals, providing more security to entrepreneurs and employees;

- Financial costs: companies need to remain technologically updated, either in equipment or software and, moreover, need to invest in staff training and process improvement, seeking quality signals (such as certifications). Required investments are high. According to our sample, it is necessary to create appropriate financing tools and subsidized rates so that companies can sustain investment and growth over time.A similar constraint applies to investments in physical infrastructure;

- $\quad$ Specialized workforce: though Ribeirão Preto forms annually a significant number of professionals in the IT field, companies find significant costs in adapting the skills of these workers to their particular needs. In general, companies need to invest in further training so professionals can meet their current demands;

- Technological training center, training center in programming language, foreign language training and continued training of human resources: higher education has failed to meet the growing demands in different fields of technology. Still, companies and education institutions acknowledge that there is a gap between professional training and what the market needs exactly. The lack of professional fluency in foreign languages hinders the capacity of being competitive at the international level (and it harms competitiveness in the domestic market regarding subsidiaries of foreign firms); - Bureaucracy in public calls: there is a great deal of complexity in preparing projects for fundraising from public initiatives. PISO's members have identified a lack of professional organizations that provide managerial support for participation in public calls, while internally they lack the abilities and/or time necessary to engage in such activities. Additionally, whenever granted, public funds face long delays before being released;

- Intellectual Property Rights: as pointed out by entrepreneurs, these are complex and costly, which may leave unprotected development and innovation, indirectly hindering investments in improvements. On the other hand software IPR represent a complicated issue worldwide and there is a lack of agreement on how to address its particularities;

In order to organize our findings and establish a closer connection between this empirical exercise and our theoretical frameworks of reference, table 4 offers an articulation of our results according to the dimensions outlined in our methodological design.

\section{Concluding remarks}

This study presents some exploratory conclusions that can be drawn from our case study regarding the role played by a moderating body in the process of centralizing the governance structure of an industrial agglomeration in the city of Ribeirão Preto, Brazil. As pointed out in our assessment, this is a largely unexplored field in the analysis of industrial agglomerations. Tripsas et al (1995), focusing on cooperative R\&D networks, have proposed that moderating agents in the dynamics of inter-firm relationships can significantly reduce transaction costs, thus enhancing overall systemic performance. In clusters, as we have found, the role of this centralized body that articulates governance among agents can also enhance the generation of externalities and improve aggregate connections with external firms and institutions. It is worth mentioning that this is an ongoing research that aims at understanding in more depth the systemic dynamics of this particular software cluster, the externalities it generates locally and its main constraints over time. 
The theoretical field of clusters has been steadily gaining ground in academic studies and policymaking processes as phenomena such as the Silicon Valley continuously generate growth and innovation, functioning as a true economic powerhouse for large geographical territories (sometimes extrapolating regional or even national boundaries). These analyses generally have sought to emphasize the characteristics of clusters' productive organization, identifying and analyzing endogenous elements of local systems. The major concern of these studies has been to identify the main features of agglomeration, which are able to provide firms with increments in their competitive capabilities. In sum, the "Collective Efficiency" generated in these economic arrangements largely justifies concern over industrial agglomerations, as it aggregates competitiveness to whole sets of firms. This is a result of economic externalities, known for its unmarketable interdependencies between agents and institutions.

There are two sources of these competitive advantages. First, incidental or pure external economies represent a result of the almost natural geographic concentration of producers in space. Among the main factors related to the generation of these externalities, it is worth noting the existence of a number of workers with specific skills and abilities, the attraction of specialized suppliers of inputs, machinery and services and spillovers generated from the concentration of capabilities accumulated locally.

\begin{tabular}{|c|c|}
\hline Topic & Main Characteristics \\
\hline Geographical location & $\begin{array}{l}\text { Economic development of the city, inflow of investments, proximity to the capital of the } \\
\text { State of São Paulo, concentration of institutions of higher education, training and avail- } \\
\text { ability of skilled labor, availability of resources, commercial facilities. The cluster has } \\
\text { strengthened the local service sector. Availability of new technologies has led the city to } \\
\text { demand more and more software development for various sectors of the regional econo- } \\
\text { my. Professionals and technology companies begin to fill these gaps in the development } \\
\text { and supply of software. Larger firms in the industry have realized existing opportunities } \\
\text { and the chance to jointly develop the sector. PISO emerges as a concerted effort to form } \\
\text { a centralized governance structure to enhance the agglomeration's capabilities. }\end{array}$ \\
\hline $\begin{array}{l}\text { Interaction and cooper- } \\
\text { ation among the com- } \\
\text { panies }\end{array}$ & $\begin{array}{l}\text { Nine entrepreneurs have realized that the development of the software industry in Ri- } \\
\text { beirão Preto could be achieved more effectively if efforts were undertook in an organized } \\
\text { and systematic way by firms located in the region. PISO arises as a nonprofit association } \\
\text { concerned about strategic issues and seeking for competitive advantage for the industry. } \\
\text { Currently, business associates interact through meetings, study groups, training, several } \\
\text { types of research projects and consulting. }\end{array}$ \\
\hline $\begin{array}{l}\text { Rivalry as a factor of } \\
\text { competitiveness: }\end{array}$ & $\begin{array}{l}\text { PISO's members do not behave as rivals. The goal of the organization of the sector } \\
\text { through PISO is to enhance overall competitiveness for the software industry in the } \\
\text { region of Ribeirão Preto. This situation is most likely due to the specificity of markets } \\
\text { in which each company operates, as well as the growing demand for software develop- } \\
\text { ment. The lack of a Pareto optimality in terms of economic equilibrium leaves room for } \\
\text { joint growth in the region. }\end{array}$ \\
\hline $\begin{array}{l}\text { Interactive learning and } \\
\text { search for innovation }\end{array}$ & $\begin{array}{l}\text { PISO's members constantly seek for development of their professional capabilities and } \\
\text { skills. There is a consensus among these entrepreneurs that educational institutions have } \\
\text { not exactly formed professionals that the industry has demanded. This occurs with more } \\
\text { intensity in the technical area, but it is also significant in the area of business analytics. }\end{array}$ \\
\hline $\begin{array}{l}\text { Collective efficiency of } \\
\text { deliberate joint initia- } \\
\text { tives between agents }\end{array}$ & $\begin{array}{l}\text { PISO has well-developed links with the city and with the public in general, as well as } \\
\text { with higher education institutions. There are still very incipient and dysfunctional ac- } \\
\text { tions due to lack of planning and interest from other agents. Public policies can be an } \\
\text { interesting solution to direct the efforts of all agents involved in the sector in search for } \\
\text { efficiency and higher returns for the region. }\end{array}$ \\
\hline $\begin{array}{l}\text { Governance mecha- } \\
\text { nisms }\end{array}$ & $\begin{array}{l}\text { The creation of PISO was important and it is crucial for the convergence of efforts for } \\
\text { all stakeholders to achieve higher levels of competitiveness. In this regard, several ini- } \\
\text { tiatives are developed by PISO, but there is still no effective model of governance that } \\
\text { makes the role of all stakeholders in the sector clear, and that can direct the efforts in a } \\
\text { more convergent and effective way. }\end{array}$ \\
\hline
\end{tabular}

Table 4. Summary of Results

ISSN: 07I 8-2724. (http://www.jotmi.org)

Journal of Technology Management \& Innovation (c) Universidad Alberto Hurtado, Facultad de Economía y Negocios. 
Second, the positive externalities could be due to a greater scope for establishing deliberate joint action between agents participating in the cluster. The geographical proximity between producers and sociocultural identification associated with concentration can stimulate more frequent maintenance of interactions. The deliberate joint action among producers therefore has the effect of amplifying the effects of external economies, contributing to strengthening corporate competitiveness through an improved environment in terms of transaction costs. While externalities observed in this study arise mostly spontaneously, through the division of labor and geographic proximity and interaction between institutions, PISO's role as a catalyst in this process must be underscored, as our results strongly suggest.

These externalities allowed an evolutionary shift towards an "efficiency frontier", as dissemination of knowledge and training of personnel took place. Consequently, externalities unraveled in a reciprocal manner, benefiting the whole productive system of software companies in Ribeirão Preto. Interestingly, as previously outlined, the cluster under scrutiny has a balance of power without any clear leader. The natural governance system is of an inherently cooperative nature. PISO emerges as a way to explore agglomeration's externalities and other sources of competitive advantage through a centralized formal body of governance among agents. Most likely, key factors driving this phenomenon are the lack of direct rivalry among members, which is due to market specificities of firms (high level of specialization), and to the current inexistence of a Pareto equilibrium in terms of supply and demand for software services in the region.

In this regard it should be emphasized the role of local public policies. Public sector support should concentrate in the provision of services and information to producers who are able to enhance the cluster's corporate competitiveness. In return, there would be generation of positive externalities that benefit the local economic system as a whole, create positive feedback loops for the regional economy. Nonetheless, as pointed out in our empirical section, PISO has been able to establish a closer relationship with governmental bodies regarding the software cluster interests. This unified channel of communication has significantly enhanced the bargain power of the agglomeration.

To sum up, PISO arises as an economic institution the context of Ribeirão Preto's software cluster that structures collective action within the system, interfering in the regional policymaking processes and fostering an environment that improves overall capabilities that allow firms to take full advantage of the externalities in order to create and consolidate competitive local advantages.
While we do not neglect the central role played by chance in the formation process of industrial agglomeration (Krugman, 1991; 1998a; 1998b), we see no reason why clusters should not be part of institutional frameworks in the policymaking realm. Considering the set of benefits that clusters have upon regional development, further knowledge regarding their socioeconomic dynamics and the role that centralized governance structures are likely to play become a subject of paramount interest in the fields of economics and managerial science (as suggested by Florida, 1995). However, drawing from Porter (1998), we also believe that such interventions should focus on enhancing the capabilities of previously existing agglomerations, as top-down planning may severely harm the natural dynamics of economic systems.

However, this research does not go without its limitations. Results are based upon one case study without proper quantitative and objective measurements that allow a cross-check of the information provided. Furthermore, a static analysis hinders the evaluation of trends that evolve over time. The conclusions, thus, are to be taken as exploratory information, guiding future research for similar contexts, functioning as an initial analytical framework. Avenues for further assessments in the realm of centralized bodies of governance in clusters should be oriented towards ex ante and ex post (regarding the implementation of this body) evaluations of Collective Efficiency in industrial agglomerations. 


\section{Notes}

There is a fifth dimension proposed by Sugden et al (2005) which makes reference to Public Policies related to the cluster under scrutiny. While we recognize the relevance of this aspect, it is beyond the scope of this article.

The region's software companies work primarily with software for managerial tasks. The most relevant competitors are multinational companies with offices in Brazil.

RAIS is a governmental initiative in Brazil that aims at collecting and distributing yearly data and reports regarding the national social environment.

Among the software companies in the region, 43 are associated with the PISO, which represents roughly half of the total population of enterprises.

Softex is a Brazilian association that functions as a catalyst for the national ICT sector regarding sectoral support for increasing competitiveness in indigenous firms.

\section{References}

ASHEIM, B., \& Gertler, M. The Geography of Innovation: Regional Innovation Systems. In: Fagerberg, J., Mowery, D., Nelson, R. (eds). The Oxford Handbook of Innovation, Oxford, Oxford University Press. doi: http://dx.doi.org/ 10.1093/ oxfordhb/9780199286805.003.00I I

BARQUERO,A.V. (2005). Las Nuevas Fuerzas del Desarrollo. Barcelona, Antoni Bosch.

BATHELT, H., \& Taylor, M. (2002). Clusters, Power and Place: Inequality and Local Growth in Time-Space. Geografiska Annaler, 84 (2), 93-109. doi: http://dx.doi.org/l0.। I I I/j.04353684.2002 .001 I $6 . x$

BIANCHI, P. (1996). Nuevo Enfoque en el Diseño de Políticas para las PYMES:Aprendiendo de la Experiencia Europea. Documento de Trabajo CEPAL n.72.

BRESCHI, S., \& Malerba, F. (1997). Sectoral Innovation Systems: Technological Regimes, Schumpeterian Dynamics, and Spatial Boundaries. In: Edquist, C.(ed). Systems of Innovation: Technologies, Institutions, and Organizations. London, Pinter.

CASAROTTO, N., \& Pires, L.H. (200I). Redes de Pequenas e Médias Empresas e Desenvolvimento Local: Estratégias para a Conquista da Competitividade Global. São Paulo, Atlas.
CASSIOLATO, J., \& Lastres, H. (2002). O Enfoque em Sistemas Produtivos e Inovação Locais. In: Fischer,T. (ed.). Gestão do Desenvolvimento e Poderes Locais: Marcos Teóricos e Avaliação. Salvador, Casa da Qualidade.

CASSIOLATO, J., \& Lastres, H. (2003). O Foco em Arranjos Produtivos e Inovativos Locais de Micro e Pequenas Empresas. In: Lastres, H., Cassiolato, J., Maciel, M. (eds.). Pequenas Empresas: Cooperação e Desenvolvimento Local. Rio de Janeiro, Relume Dumará.

COOKE, P., Uranga, M., \& Etxebarria, G. (1997). Regional Innovation Systems: Institutional and Organizational Dimensions. Research Policy, 26, 475-49I. doi: http://dx.doi. org/I0.1016/S0048-7333(97)00025-5

FLORIDA, R. (1995). Toward the Learning Region. Futures, 27(5), 527-536. doi: http://dx.doi.org//0.4337/978/8472055 37.00011

FRIGERO, B.M. (2006). A Transformação do Modelo Italiano: 1980-2005. I Encontro dos APLs do Paraná. Curitiba, CIETEP.

GEREFFI, G. (1994). The Organization of Buyer-Driven Global Commodity Chains: How U.S. Retailers Shape Overseas Production Networks. In: Gereffi, G., \& Korzeniewicz, M. (eds.). Commodity Chains and Global Capitalism. London, Greenwood Press.

KOLSTAD, C.D. (2000). Environmental Economics. New York, Oxford University Press.

KRUGMAN, P. (199I). Geography and Trade. Cambridge, MIT Press.

KRUGMAN, P. (1998a). What's New About the New Economic Geography? Oxford Review of Economic Policy, I4(2), 7-I7. doi: http://dx.doi.org/10.1093/oxrep/|4.2.7

KRUGMAN, P. (1998b). The Role of Geography in Development. Annual World Bank Conference on Development Economics.Washington, D.C.,April 20-2I.

LASTRES, H., \& Cassiolato, J. E. (2003). Novas Políticas na Era do Conhecimento: O Foco em Arranjos Produtivos e Inovativos Locais. Parcerias Estratégicas, 17, 5-29.

LIN, H., Huang, H., Lin, C., \& Hsu,W. (20I2). How to Manage Strategic Alliances in OEM-Based Industrial Clusters: Network Embeddedness and Formal Governance Mechanisms. Industrial Marketing Management, 4I, 449-459. doi: http:// dx.doi.org/10.1016/j.indmarman.201 I.04.003 
LORENZEN, M. (2005). Why Do Clusters Change? European Urban and Regional Studies, 12(3), 203-208. doi: http:// dx.doi.org/I 0.1 I 77//0969776405059046

MARKUSEN,A. (1996). Sticky Places in Slippery Space:A Typology of Industrial Districts. Economic Geography, 72(3), 293-3 |3. doi: http://dx.doi.org//0.2307//44402

MARSHALL, A. (1920). Industry and Trade: A Study of Industrial Technique and Business Organization; and of their Influences on the Condition of Various Classes and Nations. London, MacMillan.

MARSHALL, A. (1982). Princípios de Economia. São Paulo, Abril Cultural.

MARSHALI, A. (1985). Princípios de Economia: Tratado Introdutório. São Paulo, Nova Cultural.

MEYER-STAMER, J., \& Harmes-Liedtke, U. (2005). How to Promote Clusters. Competitividad: Conceptos y Buenas Practicas. Una Herramienta de Autoaprendizage y Consulta. Duisbrug and Buenos Aires, Inter-American Development Bank.

MORGAN, K. (1997). The Learning Region: Institutions, Innovation and Regional Renewal. Regional Studies, 3 I (5), 49I503. doi: http://dx.doi.org//0.4337/978/847205537.000/3

PORTER, M.E. (1990). The Competitive Advantage of Nations. London, MacMillan.

PORTER, M.E. (1998). Clusters and the New Economics of Competition. Harvard Business Review, 6, 77-90.

PORTER, M.E. (1999). Clusters e Competitividade. HSM Management. 3(I5), I00-II0.

PORTER, M.E. (2000). Nova Era da Estratégia. HSM Management. I(I), I8- 28.

PORTER, M.E. (200I). Clusters and Competitiveness: Findings from the Cluster Mapping Project. Sloan Industry Centers. Cambridge, April 12.

RAIS (20I2). Relação Anual de Informações Sociais: Microdados. Brasília, Governo Federal.

REINAU, K.H., \& Dalum, B. (2008). The Role of Governance in Cluster Typologies:A Missing Link. 25th DRUID Celebration Conference: Entrepreneurship and Innovation - Organizations, Institutions, Systems and Regions. Copenhagen, June 17-20.
SARACENI, A., \& Andrade Júnior, P. (2012). Analysis of Aspects of Innovation in a Brazilian Cluster. Journal of Technology Management \& Innovation, 7(3), 207-2 I3. doi: http:// dx.doi.org/I0.4067/s07/8-272420I20003000I7

SCHMITZ, H. (1997). Eficiência Coletiva: Caminho de Crescimento para a Indústria de Pequeno Porte. Ensaios FEE, I8(2), I64-200.

SCHMITZ, H. (1999). Global Competition and Local CoOperation: Success and Failure in the Sinos Valley, Brazil. World Development, 27(9), 1627-1650. doi: http://dx.doi. org/I0.1016/s0305-750x(99)00075-3

SCOTT,A. (1998). The Geographic Foundations of Industrial Performance. In: Chandler,A., Hagstron, P., \& Solvell, O. (eds.). The Dynamic Firm: the Role of Technology, Strategy, Organization, and Regions. Oxford University Press, Oxford. doi: http://dx.doi.org/I0.1093/0198296045.003.00I6

SHEARMUR, R. (20II). Innovation, Regions and Proximity: From Neo-Regionalism to Spatial Analysis. Regional Studies, 45(9), I225-1243. doi: http://dx.doi.org// 0.1080/00343404.2 010.484416

STORPER, M., \& Harrison, B. (199I). Flexibility, Hierarchy and Regional Development:The Changing Structure of Industrial Production Systems and Their Forms of Governance in The 1990s. Research Policy, 20(5), 407-422. doi: http://dx.doi. org/l0.1016/0048-7333(9I)90066-y

STORPER, M., \& Scott, A. (1995). Market Forces and Policy Imperatives in Local and Global Context. Futures, 27(5), 505-526.

STURGEON, T. (1997). Turn-Key Production Networks: A New Model of Industrial Organization? BRIE Working Paper n.92A.

SUGDEN, R., Wei, P., \& Wilson, J. (2005). Clusters, Governance and the Development of Local Economies: A Framework for Case Studies. In: Pitelis, C. Sugden, R., Wilson, J. (eds). Clusters and Globalization:The Development of Economies. Cheltenham, Edward Elgar. doi: http://dx.doi.org// 0.4 $337 / 978$ I847200I36.000 I I

SUZIGAN, W., Furtado, J., Garcia, R., \& Sampaio, S. (2003). Sistemas Locais de Produção: Mapeamento,Tipologia e Sugestões de Políticas. Anais do XXXI Encontro Nacional de Economia, Porto Seguro, December 9-12. 
SUZIGAN, W., Garcia, R., \& Furtado, J. (2003). Governança de Sistemas Produtivos Locais de Micro, Pequenas e Médias Empresas. In: Lastres, H., Cassiolato, J., Maciel, M. (eds.). Pequena Empresa: Cooperação e Desenvolvimento Local. Rio de Janeiro, Relume Dumará.

SUZIGAN, W. (2000). Aglomerações Industriais: Avaliação e Sugestões de Políticas. In: Ministério do Desenvolvimento, Indústria e Comércio Exterior (ed.). O Futuro Da Indústria: Oportunidades e Desafios. Brasília, MDIC.

TRIPSAS, M., Schrader, S., \& Sobrero, M. (1995). Discouraging Opportunistic Behavior in Collaborative R\&D:A New Role for Government. Research Policy, 24, 367-389. doi: http:// dx.doi.org/I0.1016/0048-7333(93)0077I-k

TRISTÃO, H., Oprime, P., Jugend, D., \& Silva, S. (20I3). Innovation in Industrial Clusters: A Survey of Footwear Companies in Brazil. Journal of Technology Management \& Innovation, 8(3), 45-56. doi: http://dx.doi.org/I0.4067/s07 I827242013000400005

TURVEY, R. (1963). On Divergences between Social Cost and Private Cost, Economica, 30 (I 19), 309-3 I3. doi: http:// dx.doi.org//0.2307/260I550

WILLIAMSON, O.E. (1985). The Economic Institutions of Capitalism. New York, Free Press.

YIN, R.K. (200I). Estudo de Caso: Planejamento e Método. 